МРНТИ 06.61.33

JEL Classification: R10

https://doi.org/10.52821/2224-5561-2021-2-141-148

METHODS FOR ASSESSING THE PERFORMANCE OF REGIONAL PROGRAMS

\author{
S. E. Rymbekov ${ }^{1 *}$, M. P. Loginov ${ }^{2}$ \\ ${ }^{1}$ Karaganda University of Kazpotrebsoyuz, Karagandy, Republic of Kazakhstan \\ ${ }^{2}$ Ural State Economic University, Yekaterinburg, Russian Federation
}

\begin{abstract}
The purpose of the research is study and define methods for evaluating the effectiveness of regional programs

Methodology - in the course of the study, methods of comparative analysis, analogies, generalizations, classification, systemic and structural approaches, as well as the theory of strategic management at the city level were used. The research information base includes data from the Bureau of National statistics of Agency for Strategic planning and reforms of the Republic of Kazakhstan, the Ministry of Regional Development of the Republic of Kazakhstan, as well as information published in foreign publications.

Originality / value of the research. The study carried out a comprehensive multilateral assessment of the effectiveness of regional programs, which is a system of indicators characterizing regional programs in different aspects.

Findings - the ways of increasing the efficiency of regional programs by means of their separation and periods of implementation are proposed, ensuring their continuity in achieving a comprehensive effect. Recommendations are given to regional authorities and administrations to improve the effectiveness of the main regional programs in the short and long term.

Keywords: region, regional management, strategic planning, regional programs, the effectiveness of regional programs.
\end{abstract}

\title{
INTRODUCTION
}

Currently, the Republic of Kazakhstan is faced with the tasks of increasing the well-being of the population and modernizing the economy, the solution of which depends on the quality of regional management of budgetary funds. Over the past few years, the programmatic method of regional management has received significant development. The main goal of introducing this mechanism is to ensure an increase in the efficiency of spending and managing budget funds at all levels of government. In this connection, it becomes necessary to analyze the existing methods for assessing the effective spending of each tenge within the framework of regional programs, to identify their shortcomings, as well as to develop a methodology for assessing the spending of budgetary funds that most fully takes into account the criteria of their effectiveness [1].

In the context of regional programs, the views of economists on the effectiveness of their implementation differ so, L. Padilla Sarosa and M.E. Chichelov define efficiency as the ratio of budgetary costs for the implementation of activities and the effect of the result obtained.

T. Silvestrova understands efficiency as "the achievement of the set goals and objectives within the framework of the implementation of regional programs by correlating the results obtained and the costs incurred".

K. O. Tarkhanovsky believes that the effective use of budgetary funds can be considered the preparation and execution of budgets in conjunction with the allocated resources and assigned tasks.

In addition, using the results of previous author's studies of criteria and indicators for assessing the effectiveness of program expenditures used by the subjects of the Republic of Kazakhstan, all methods can be 
divided into two groups. The first group includes regions that use methodological recommendations developed by the Ministry of National Economy of the Republic of Kazakhstan.

The second group is made up of regions that use their own unique indicators and assessment criteria, such as:

- compliance of the goals of the regional development strategy with the priorities of state policy;

- quality of management;

- attraction of funds from extrabudgetary sources;

- budgetary and economic efficiency;

- achievement of target indicators;

- community participation;

- description of risks and external factors;

- completeness of use of funds;

- the degree of implementation of the activities;

- openness and publicity of data

As a result of the analysis, the best practices for assessing the effectiveness of regional programs of the subjects of the Republic of Kazakhstan were selected.

The effectiveness of the application of the target-oriented method is determined by its ability to mobilize resources to solve such problems that go beyond the current or strategic planning of the development of a region or a municipality. Distinctive features of this method are: concentration of resources on solving specific problems; precise definition of the timing of achieving the goals; measurability of expected results; concentration of responsibility of the main executors of the programs before the regional authorities [2].

The main advantages of the program-targeted method of regional and municipal management of regions can be manifested in such areas as regional social policy, territorial development, environmental policy, development and support of entrepreneurship, etc.

\section{MAIN PART}

Implementation of regional programs requires a dedicated programmatic assessment tool.

Evaluation of the effectiveness of regional programs in the Republic of Kazakhstan is a relatively new instrument of regional policy implementation. In the period 2015-2020 the subjects of the Republic of Kazakhstan, relying on state guidelines, have developed their own methods for assessing the effectiveness of regional programs. To identify the most objective, transparent and high-quality methodology, an analysis of the approaches of the subjects of the Republic of Kazakhstan to the assessment of regional programs was carried out, which made it possible to identify the parameters by which they differ:

- the authority that approved the methodology and is responsible for evaluating the programs;

- qualitative indicators of program evaluation;

- quantitative indicators for evaluating programs; evaluating the implementation of major activities;

- assessment of the financial support of programs;

- efficiency of program implementation;

- assessment of the quality of program management;

- information transparency, publicity of information about the implementation of programs;

- ranking according to the degree of implementation

- risks, consequences, external factors and others.

The approaches are united by the general principle of assessment, which consists in the ratio of the actual budget expenditures and the achieved targets to the planned values. The methodologies differ in that some regions calculate the level of achievement of the target indicators of programs, while others calculate the dynamics of changes in target indicators over the years. The analysis of the dynamics characterizes the general trend in the implementation of the regional program, which is of great importance in the field of regional management [3].

Indicators in the assessment are applied both qualitative and quantitative. However, only $22 \%$ of all regions use qualitative criteria, which is due to the complexity of their formalization when calculating the level of efficiency and the fact that they are mainly used at the stage of program development (compliance of the goal with strategies, priorities of state policy; level of elaboration of indicators, elaboration of indicators, etc.) [4]. 
When evaluating regional programs, special attention is paid to the main measures for their implementation (53\%), including the assessment of the correctness of their formulations, the degree of timeliness of implementation, as well as comparing their effectiveness with the previous year.

Methods for assessing the effectiveness of the implementation of regional programs $13 \%$ of all subjects take into account the amount of funds raised from the budgets of other levels, as well as extra-budgetary funds, their structure and dynamics compared to the previous year [5].

Indicators of the quality of program management are used in $18 \%$ of regions, which consist in assessing the activities of administrators, taking into account the number of changes, and a timely performance report. However, these indicators are characterized by a low degree of objectivity.

The criteria used, in most cases, make it possible to report on the use of budget funds with a sufficiently high degree of efficiency of the existing programs, which actualizes the task of developing an objective assessment methodology [6].

Methods for assessing the effectiveness of regional programs of the subjects of the Republic of Kazakhstan can be grouped, taking into account some of their features. A number of methods of subjects, which are used by more than $65 \%$ of regions of Kazakhstan, imply the calculation of an integrated indicator, using either a point assessment or taking into account the significance of specific indicators of achieving goals, as a result of which they are distributed into groups according to the degree of their effectiveness [7]. Usually, a three-tier system is used, for example, in the Karaganda region, the regions of the program are divided into effective, insufficiently effective and ineffective; in the Almaty region - a high level of efficiency, satisfactory and unsatisfactory levels. The city of Nursultan applies a five-level ranking - highly effective, efficient, insufficiently effective, and ineffective [8].

All techniques can be divided into two groups. The first group includes regions that use methodological recommendations developed by the Ministry of Economic Development of the Republic of Kazakhstan. The second group consists of regions that use, along with regional recommendations, their own unique indicators and assessment criteria, which are presented in Table 1 [9].

Table 1 - Criteria for assessing the effectiveness of regional programs of the subjects of the Republic of Kazakhstan

\begin{tabular}{|l|l|l|l|l|l|l|l|}
\hline & & & & & & & \\
\\
\end{tabular}


As a result of the study of regulatory legal acts to assess the effectiveness of regional programs in the subjects of the Republic of Kazakhstan, it is possible to highlight the disadvantages and advantages of the methods. It is worth noting the methods of Almaty, Atyrau and other regions that use indicators of budgetary efficiency. Akmola region, as well as other regions - indicators of the quality of management of programs and subprograms [10].

At the same time, today there are already a number of approaches to assess the effectiveness of the implementation of regional target programs. In particular, most often the assessment is carried out on the basis of comparing the planned indicators of achievement of the goals declared in the program with the actual ones. A possible scale for assessing the effectiveness of targeted programs may look as follows (see Table 2) [11].

Table 2 - Scale of qualitative assessment of the effectiveness of regional target programs

\begin{tabular}{|c|c|c|c|}
\hline $\begin{array}{l}\text { The rank of the program's } \\
\text { contribution to the strategy of } \\
\text { the region }\end{array}$ & $\begin{array}{c}\text { Degree of } \\
\text { achievement of } \\
\text { key indicators, } \%\end{array}$ & $\begin{array}{l}\text { Evaluation of the } \\
\text { results }\end{array}$ & Possible management decisions \\
\hline \multirow[t]{4}{*}{ Tall } & $80-100$ & High & $\begin{array}{l}\text { Recommend full funding for the target program. } \\
\text { Completion of initiated activities is required }\end{array}$ \\
\hline & $60-79$ & Good & Recommend to keep the same level of funding \\
\hline & $30-59$ & Satisfactory & Funding justification needed \\
\hline & $0-29$ & Unsatisfactory & $\begin{array}{l}\text { The need to complete the initiated activities when } \\
\text { a high degree of validity of the requested amounts of } \\
\text { budget funds }\end{array}$ \\
\hline \multirow[t]{4}{*}{ Middle } & $80-100$ & High & $\begin{array}{l}\text { Recommend full funding of the target program with the } \\
\text { possibility of revising some of the targets }\end{array}$ \\
\hline & $60-79$ & Good & $\begin{array}{l}\text { Recommend to maintain the previous level of funding, } \\
\text { subject to its revision }\end{array}$ \\
\hline & $30-59$ & Satisfactory & $\begin{array}{l}\text { Finalize the target program with a temporary suspension } \\
\text { of financing costs }\end{array}$ \\
\hline & $0-29$ & Unsatisfactory & Termination of funding \\
\hline \multirow[t]{4}{*}{ Low } & $80-100$ & High & $\begin{array}{l}\text { Recommend full funding of the target program with the } \\
\text { possibility of revising some of the targets }\end{array}$ \\
\hline & $60-79$ & Good & $\begin{array}{l}\text { Recommend full funding of the target program with the } \\
\text { possibility of revising some of the targets }\end{array}$ \\
\hline & $30-59$ & Satisfactory & $\begin{array}{l}\text { A high degree of justification for the continuation of the } \\
\text { financing of the targeted program }\end{array}$ \\
\hline & $0-29$ & Unsatisfactory & Early termination of the target program \\
\hline
\end{tabular}

Therefore, in our opinion, to assess regional target programs, it is necessary to equally use both performance indicators and performance indicators, with the subsequent determination of the integral indicator (Figure 1) [12].

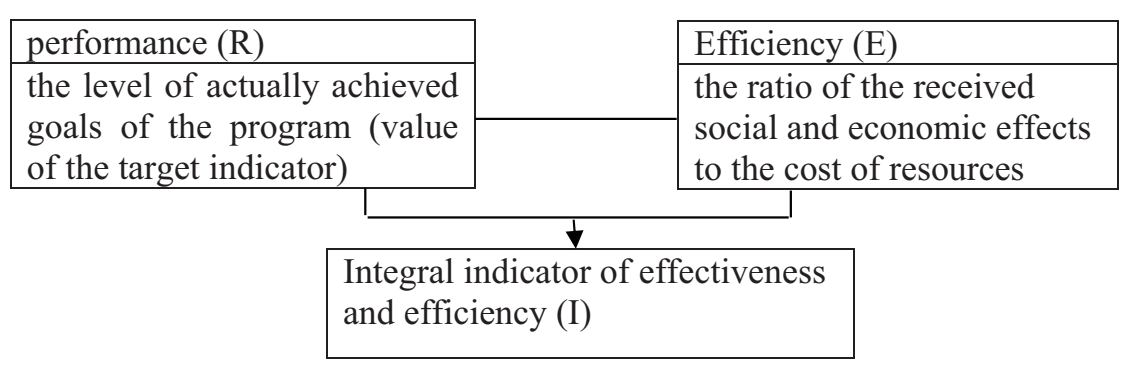

Figure 1 - The system of criteria for assessing the effectiveness and efficiency of regional target programs Note-Compiled by the authors 
Within the framework of the proposed methodology, these criteria should be integrated into an integral indicator of efficiency and effectiveness for subsequent comparative analysis of programs in areas and priorities of implementation, which can be calculated by the formula:

$$
\Delta \mathrm{I}=\mathrm{K} 1 \Delta \mathrm{R}+\mathrm{K} 2 \Delta \mathrm{E},
$$

Where, $\Delta \mathrm{I}-$ is an integral indicator (index) of effectiveness and efficiency;

$\Delta \mathrm{R}, \Delta \mathrm{E}$ - actual indicators of the effectiveness and efficiency and adaptability of the implemented programs (in full or in part) for the studied period of time;

$\mathrm{K} 1, \mathrm{~K} 2$ - correlation coefficients reflecting the weight value of each indicator in the structure of the integral indicator (index) [13].

\section{RESEARCH RESULTS AND CONCLUSIONS}

Thus, program-targeted management is one of the effective methods of strategic management both at the regional and municipal levels. Regional and municipal target programs today solve important development problems in the social sphere, in the field of housing and road construction, education, health care, etc. high motivation of the main performers to achieve goals, it has been possible to achieve serious results recently. An important advantage of this approach is the possibility of using it to implement the main priorities of sustainable development of the territory in the long term [14].

However, great attention should be paid to the issues of the effectiveness of the implementation of regional and municipal target programs. In this regard, an integrated approach is needed to assess the effectiveness, the development of criteria that would take into account all the features of the implementation of a specific program. The system of criteria should take into account, on the one hand, the direction of the program (economy, social sphere, infrastructure development, etc.), and on the other hand, the period of the program implementation (longterm, medium-term and short-term). It is advisable to assess the level of implementation of regional and municipal target programs according to criteria such as efficiency and effectiveness. An integral indicator of efficiency and effectiveness can serve as optimal for this, which allows, on the one hand, to assess the degree of achievement of the goals set in the programs, and on the other hand, the level of budgetary costs for their achievement [15].

In conclusion, it should be noted that the degree of sustainability of the region will increase with the transition to program-targeted methods of management of the region and the municipality, as well as performance-based budgeting. At the same time, it is necessary to promote the development of adequate criteria for assessing the effectiveness of regional and municipal target programs.

\section{REFERENCES}

1. Указ Президента Республики Казахстан от 4 декабря 2001 года N 735 О дальнейших мерах по реализации Стратегии развития Казахстана до 2030 года. Утратил силу Указом Президента Республики Казахстан от 1 февраля 2010 года N 922. [Electronic source] // Әділет [web-portal]. - 2001. - URL: http:// adilet.zan.kz/kaz/docs/U010000735_(accessed: 16.01.2020).

2. О параметрах индикативного плана социально-экономического развития Республики Казахстан на 2001-2003 годы. Постановление Правительства Республики Казахстан № 722 от 15 мая 2000 г. [Electronic source] // Әділет [web-portal]. - 2000. - URL: http://adilet.zan.kz/kaz/docs/P000000722_ (accessed: 12.01.2020).

3. Елеусин С. Н. Третья модернизация Казахстана: цели, задачи, механизмы [Electronic source] // Казахстанская правда [website]. - 2017. - URL: https://kazpravda.kz/articles/view/tretya-modernizatsiyakazahstana-tseli-zadachi-mehanizmi/ (accessed: 10.04.2017).

4. Спанова Б. Ж. Методы управления региональной экономикой Республики Казахстан [Electronic source]. - 2008. - URL: http://www.rusnauka.com/10_NPE_2008/Economics/29314.doc.htm (accessed: 10.01.2020). 
5. Вечкинзова Е. А. Анализ ситуации регионального управления в Казахстане // Вестник Чувашского университета - 2009. - № 3. - С. 392-396.

6. Нурмуханова Г. Ж. Формирование конкурентоспособной экономики Республики Казахстан: методологические подходы, проблемы и перспективы развития: Автореферат диссертации на соискание ученой степени доктора экономических наук. - Алматы, 2008. - 331 с.

7. Текенов У. А. О формировании концепции социально-экономического развития регионов Казахстана // Вестник КазЭУ. - 2016. - № 6. - С. 23-33.

8. Раимбеков С. Модернизация системы регионального и местного самоуправления [Electronic source] // Информационный портал Zakon.Kz [web-portal]. - 2006. - URL: https://www.zakon.kz/79735modernizacija-sistemy-regionalnogo-i.html (accessed: 05.01.2020).

9. На каких регионах Казахстана держится вся экономика страны [Electronic source] // МК в Казахстане [web-site]. - 2019. - URL: https://mk-kz.kz/economics/2019/12/10/na-kakikh-regionakh-kazakhstanaderzhitsya-vsya-ekonomika-strany.html (accessed: 10.01.2019).

10. Коршунов Д. В. Региональная политика в Республике Казахстан: дипломная работа. - Костанай, 2010. -42 c.

11. Янчук Э. Т., Воронова Т. Э. Каппасова Г. М. Система государственного управления в Республике Казахстан: Учебно-методическое пособие. - Павлодар: Кереку, 2008. - 64 с.

12. Названы семь приоритетов экономического развития Казахстана [Electronic source] // Forbes.kz [web-site]. - 2018. - URL: https://forbes.kz/process/economy/nazvanyi_sem_prioritetov_ekonomicheskogo_ razvitiya_kazahstana (accessed: 07.09.2018).

13. Тихонов A. Казахстан: как развитие страны разводит регионы [Electronic source] // CAA\&RC Экспертный портал KazakhSTAN 2.0 [web-portal]. - 2017. - URL: https://kz.expert/ru/materials/analitika/123_ kazahstan_kak_razvitie_strani_razvodit_regioni (accessed: 24.11.2017).

14. Потенциал регионов - основа для формирования сильного Казахстана [Electronic source] // Актюбинский Вестник [web-site]. - 2019. - URL: https://avestnik.kz/potenczial-regionov-osnova-dlyaformirovaniya-silnogo-kazahstana/ (accessed: 12.09. 2019).

15. Итоги реализации Государственной программы «Цифровой Казахстан» за 2019 год [Electronic source]//Finance.kz[web-portal].-2020.-URL:https://finance.kz/articles/itogi_realizatsii_gosudarstvennoy_ programmy_tsifrovoy_kazahstan_za_2019_god-1482 (accessed: 05.01.2020).

\section{REFERENCES}

1. "Ukaz Prezidenta Respubliki Kazahstan ot 4 dekabrya 2001 goda N 735 O dal'nejshih merah po realizacii Strategii razvitiya Kazahstana do 2030 goda. Utratil silu Ukazom Prezidenta Respubliki Kazahstan ot 1 fevralya 2010 goda N 922" (2001), available at: http://adilet.zan.kz/kaz/docs/U010000735_ (accessed: January 16, 2020) (In Russian).

2. "O parametrah indikativnogo plana social'no-ekonomicheskogo razvitiya Respubliki Kazahstan na 20012003 gody. Postanovlenie Pravitel'stva Respubliki Kazahstan № 722 ot 15 maya 2000 g.” (2000), available at: http://adilet.zan.kz/kaz/docs/P000000722_ (accessed: January 12, 2020) (In Russian).

3. Yeleusin S. N. (2017), "Tret'ya modernizatsiya Kazakhstana: tseli, zadachi, mekhanizmy", Kazakhstanskaya Pravda, available at: https://kazpravda.kz/articles/view/tretya-modernizatsiya-kazahstanatseli-zadachi-mehanizmi/ (accessed: April 10, 2017) (In Russian).

4. Spanova B. Zh. (2008), "Metody upravleniya regional'noj ekonomikoj Respubliki Kazahstan", available at: http://www.rusnauka.com/10_NPE_2008/ Economics/29314.doc.htm (accessed: January 10, 2020) (In Russian).

5. Vechkinzova E. A. (2009), "Analiz situacii regional'nogo upravleniya v Kazahstane”, Bulletin of the Chuvash University, No. 3, P. 392-396 (In Russian).

6. Nurmukhanova G. Zh. (2008), "Formirovaniye konkurentosposobnoy ekonomiki Respubliki Kazakhstan: metodologicheskiye podkhody, problemy i perspektivy razvitiya: Avtoreferat dissertatsii na soiskaniye uchenoy stepeni doktora ekonomicheskikh nauk", Almaty, 331 p. (In Russian). 
7. Tekenov U. A. (2016), “O formirovanii koncepcii social'no-ekonomicheskogo razvitiya regionov Kazahstana”, Vestnik KazEU, No. 6, P. 23-33 (In Russian).

8. Raimbekov S. (2006), "Modernizaciya sistemy regional'nogo i mestnogo samoupravleniya", available at: https://www.zakon.kz/79735-modernizacija-sistemy-regionalnogo-i.html (accessed: January 5, 2020) (In Russian).

9. "Na kakikh regionakh Kazakhstana derzhitsya vsya ekonomika strany" (2019), MK v Kazahstane, available at: https://mk-kz.kz/economics/2019/12/10/na-kakikh-regionakh-kazakhstana-derzhitsya-vsyaekonomika-strany.html (accessed: January 10, 2019) (In Russian).

10. Korshunov D. V. (2010), "Regional'naya politika v Respublike Kazahstan: diplomnaya rabota", Kostanai, 42 p. (In Russian).

11. Yanchuk E. T. \& etc. (2008), "Sistema gosudarstvennogo upravleniya v Respublike Kazahstan: Uchebno-metodicheskoe posobie", Kereku, Pavlodar, 64 p. (In Russian).

12. "Nazvany sem' prioritetov ekonomicheskogo razvitiya Kazakhstana" (2018), Forbes. $\mathrm{kz}$, available at: https://forbes.kz/process/economy/nazvanyi_sem_prioritetov_ekonomicheskogo_razvitiya_ kazahstana (accessed: September 7, 2018) (In Russian).

13. Tikhonov A. (2017), "Kazakhstan: kak razvitiye strany razvodit region", CAA\&RC KazakhSTAN 2.0 expert portal, available at: https://kz.expert/ru/materials/analitika/123_kazahstan_kak_razvitie_strani_ razvodit_regioni (accessed: November 24, 2017) (In Russian).

14. "Potentsial regionov - osnova dlya formirovaniya sil'nogo Kazakhstana" (2019), Aktyubinskij Vestnik, available at: https://avestnik.kz/potenczial-regionov-osnova-dlya-formirovaniya-silnogo-kazahstana/ (accessed: September 12, 2019) (In Russian).

15. "Itogi realizatsii Gosudarstvennoy programmy «Tsifrovoy Kazakhstan» za 2019 god" (2020), Finance.kz, available at: https://finance.kz/articles/itogi_realizatsii_gosudarstvennoy_programmy_tsifrovoy_ kazahstan_za_2019_god-1482 (accessed: January 5, 2020) (In Russian).

\title{
АЙМАҚТЫҚ БАҒДАРЛАМАЛАРДЫН ТИІМДІЛІГІН БАҒАЛАУ ӘДІСТЕРІ
}

\section{С. Е. Рымбеков ${ }^{1 *}$, М. П. Логинов ${ }^{2}$}

${ }^{1}$ Қазтұтынуодағы Қарағанды университеті, Қарағанды, Қазақстан Республикасы

${ }^{2}$ Урал мемлекеттік экономикалық университеті, Екатеринбург, Ресей Федерациясы

\begin{abstract}
АНДАТПА
Зерттеу мақссаты - аймақтық бағдарламалардың тиімділігін бағалау әдістерін зерттеу және анықтау.

Әдіснамасы - зерттеу барысында салыстырмалы талдау әдістері, ұқсастығы, жалпылауы, жіктелуі, жүйелік және құрылымдық тәсілдері, сонымен қатар қалалық деңгейдегі стратегиялық басқару теориясы қолданылды. Зерттеудің ақпараттық базасына Қазақстан Республикасы Стратегиялық жоспарлау және реформалар агенттігінің Ұлттық статистика бюросы, Қазақстан Республикасы Өңірлік даму министрлігінің мәліметтері, сондай-ақ шетелдік басылымдарда жарияланған ақпараттар кіреді.

Зерттеудің бірегейлігі / құндылызы - зерттеу барысында аймақтық бағдарламалардың тиімділігін кешенді көпжақты бағалау жүргізілді, бұл аймақтық бағдарламаларды әртүрлі аспектілерде сипаттайтын көрсеткіштер жүйесі болып табылады.

Зерттеу нәтижелері - аймақтық бағдарламалардың тиімділігін олардың бөлінуіне және іске асырылу кезеңдеріне қарай арттыру жолдары ұсынылады, олардың кешенді нәтижеге жетудегі үздіксіздігі қамтамасыз етіледі. Қысқа және ұзақ мерзімді перспективада негізгі аймақтық бағдарламалардың тиімділігін арттыру үшін аймақтық билік пен әкімшіліктерге ұсыныстар беріледі.
\end{abstract}


Түйін сөздер: аймақ, аймақтық менеджмент, стратегиялық жоспарлау, аймақтық бағдарламалар, аймақтық бағдарламалардың тиімділігі.

\title{
МЕТОДЫ ОЦЕНКИ ЭФФЕКТИВНОСТИ РЕГИОНАЛЬНЫХ ПРОГРАММ
}

\author{
С. Е. Рымбеков ${ }^{1 *}$, М. П. Логинов ${ }^{2}$
}

${ }^{1}$ Карагандинский университет Казпотребсоюза, Караганда, Республика Казахстан

${ }^{2}$ Уральский Государственный Экономический Университет, Екатеринбург, Россиийская Федерация

\begin{abstract}
АННОТАЦИЯ
Цель исследования - изучить и определить методы оценки эффективности региональных программ.

Методология - в процессе исследования использовались методы сравнительного анализа, аналогий, обобщений, классификации, системного и структурного подходов, а также теория стратегического управления на уровне городов. Информационная база исследования включает данные Бюро национальной статистики Агентства по стратегическому планированию и реформам Республики Казахстан, Министерства регионального развития Республики Казахстан, а также сведения, опубликованные в зарубежных изданиях.

Оригинальность / изенность исследования - в исследовании проведена комплексная многосторонняя оценка эффективности региональных программ, которая представляет собой систему показателей, характеризующих региональных программ в разных аспектах.

Результаты исследования - предлагаются пути повышения эффективности региональных программ посредством их эшелонирования и периодам реализации, обеспечивающим их преемственность в достижении комплексного эффекта. Даются рекомендации органам региональной власти и управления по повышению эффективности основных региональных программ в краткосрочном и долгосрочном периодах.

Ключевые слова - регион, региональное управление, стратегическое планирование, региональные программы, эффективность региональных программ.
\end{abstract}

\section{ОБ АВТОРАX}

Рымбеков Султан Егинбаевич - докторант $\mathrm{PhD}$, Карагандинский Университет Казпотребсоюза, Караганда, Республика Казахстан, e-mail: rymbekov.sultan@mail.ru*

Логинов Михаил Павлович - доктор экономических наук, доцент, Уральский Государственный Экономический Университет, Екатеринбург, Российская Федерация, e-mail: port-all@mail.ru 